\title{
PENGARUH PEMBELAJARAN SISTEM DARING TERHADAP MAHASISWA TADRIS BIOLOGI DALAM MEMAHAMI MATERI MATA KULIAH BIOKIMIA
}

\author{
Mila Yatimatul Isnayni ${ }^{1}$, Wildan Hermansyah ${ }^{1}$ \\ ${ }^{1}$ Institut Agama Islam Negeri Jember, Jl. Mataram No. 1 Mangli, Jember 68136, \\ Jawa Timur, Indonesia \\ E-mail: linariafinch@gmail.com
}

\begin{abstract}
This study aims to find out how the influence of biochemical learning conducted online system on the understanding of students of Biology at IAIN Jember. This research was conducted by giving questionnaire to respondents online. The type of itprovided is an open questionnaire, in which the respondent is free to fill in the answers according to his wishes. Based on the questionnaire, it was found that students had difficulty understanding biochemistry courses. Difficulties in understanding the sub material that has been provided through online, which is felt to be less effective, it can have an influence on the low learning achievement of Tadris biology students at IAIN Jember.
\end{abstract}

Keywords: Biochemistry, Online Learning, Biology Education.

\begin{abstract}
Abstrak: Penelitian ini bertujuan untuk mengetahui bagaimana pengaruh pembelajaran biokimia yang dilaksanakan secara sistem daring terhadap pemahaman mahasiswa Tadris Biologi IAIN Jember. Penelitian ini dilakukan dengan cara memberikan kuisioner/angket kepada responden secara online. Jenis angket yang diberikan adalah angket terbuka, yang di dalamnya responden bebas mengisi jawaban sesuai kehendaknya. Berdasarkan angket, didapatkan hasil bahwa mahasiswa kesulitan dalam memahami mata kuliah biokimia. Sulitnya dalam memahami materi yang sudah disediakan melalui online, yang dirasa kurang efektif, hal tersebut dapat memberikan pengaruh pada rendahnya prestasi belajar mahasiswa Tadris biologi IAIN Jember.
\end{abstract}

Kata Kunci: Biokimia, Pembelajaran Daring, Pendidikan Biologi.

Pandemi covid-19 telah menyebar keseluruh wilayah Indonesia sejak akhir bulan Februari lalu. Hal ini memberikan banyak perubahan terhadap kehidupan manusia dalam berbagai bidang. Salah satunya yaitu dalam bidang pendidikan. Semenjak pemerintah mengeluarkan kebijakan Pembatasan Sosial Berskala Besar (PSBB) yang lebih dikenal dengan sosial distancing, membuat dunia pendidikan tidak bisa kembali menerapkan pembelajaran konvensional. Hal ini dilakukan untuk memutus rantai persebaran covid-19. Perubahan model pembelajaran yang biasanya dilakukan secara tatap muka/konvensional menjadi pembelajaran secara online/daring.

Pembelajaran merupakan bantuan yang diberikan oleh pendidik agar dapat terjadi proses perolehan ilmu dan pengetahuan, penguasaan kemahiran, tabiat, dan pembentukan sikap pada peserta didik. Untuk memudahkan dalam prosesnya maka diperlukan strategi yang tepat. Strategi pembelajaran merupakan suatu cara atau metode yang dilakukan oleh pendidik terhadap anak didik dalam upaya terjadinya perubahan aspek kognitif, afektif, dan motorik 
secara berkesinambungan. Azhar (2011) mengatakan pembelajaran adalah segala sesuatu yang dapat membawa informasi dan pengetahuan dalam interaksi yang berlangsung antara pendidik dan peserta didik.

Menurut UUSPN NO. 20 tahun 2003 pembelajaran adalah proses interaksi peserta didik dan pendidik, serta sumber belajar pada suatu lingkungan belajar. Dalam pembelajaran dengan tatap muka secara langsung proses interaksi antara pendidik dan peserta didik sangat memungkinkan terjadi pertukaran pengalaman belajar, karena antara pendidik dan peserta didik terdapat dalam satu ruangan, sehingga proses pembelajaran dapat berjalan dengan lancar dan nyaman.

Proses pembelajaran biokimia dapat berlangsung dengan baik apabila antar mahasiswa saling bertukar pemahaman dalam mendiskusikan materi yang disampaikan. Keutamaan dari pembelajaran daring yaitu dapat dilakukan dimana saja dan kapan saja. Mahasiswa tidak perlu menghabiskan waktu berjam-jam untuk belajar di kelas. Keutamaan yang kedua, bahan belajar biokimia dapat diakses kapan saja dengan kecanggihan teknologi. Materi-materi pembelajaran biokimia tersebut dapat diunduh dan dapat dipelajari kapan saja tanpa batas waktu.

Mata kuliah biokimia adalah salah satu mata kuliah pokok yang harus dipelajari mahasiswa S1 Program Studi Tadris Biologi di IAIN Jember. Biokimia merupakan mata kuliah yang mempelajari struktur dan fungsi komponen seluler, seperti protein, karbohidrat, lipid, asam nukleat, dan biomolekul lainnya. Mata kuliah biokimia memuat materi tentang kimia reaksi diperantarai enzim dan sifat-sifat protein. Mahasiswa diharapkan mampu mengetahui dan memahami konsep dari biokimia.

Namun pemanfaatan e-learning (daring) tidak sepenuhnya berjalan dengan baik. Walaupun banyak keuntungan di dalam pembelajaran ini, tidak menutup kemungkinan kelemahan pembelajaran ini tetap ada. Yang perlu diperhatikan dari penerapan kegiatan pembelajaran daring adalah menuntut adanya komitmen baik dosen maupun mahasiswa, untuk mengoptimalkan pemanfaatan koneksi internet dan wifi guna kepentingan pembelajaran. Hal lain yang menjadi sorotan para peserta didik yaitu kesulitan dalam memahami materi yang disampaikan secara instan oleh pendidik.

Koneksi internet menjadi penentu keberhasilan pembelajaran saat ini. Koneksi internet yang terganggu saat pembelajaran berlangsung akan menjadi hambatan proses interaksi antara mahasiswa dengan dosen. Selain itu, kendala pembelajaran daring terhadap mata kuliah biokimia yaitu keaktifan dari individu menjadi terbatas, walaupun sistem daring bersifat fleksible, dengan waktu kapan saja dan di mana saja. Namun, disisi lain ada kesibukan lain baik 
dosen dan mahasiswa ketika berada dirumah masing-masing yang membuat batasan batasan dalam mempertanyakan materi yang dirasa belum paham.

Maka penelitian ini dilakukan untuk mengetahui pengaruh pembelajaran yang dilakukan secara sistem daring terhadap mahasiswa dalam memahami materi mata kuliah, khususnya materi biokomia yang dilakukan secara sistem daring.

\section{METODE}

Metode penelitian yang digunakan dalam penelitian ini adalah dengan metode kualitatif. Metode penelitian kualitatif adalah metode penelitian yang tidak dapat diukur atau dinyatakan dengan bentuk angka, penelitian ini berhubungan dengan pendapat, persepsi, ide, dan kepercayaan beberapa orang yang akan dikaji. Penelitian ini dilakukan dengan memberikan kuesioner (angket) dalam pengumpulan datanya. Kuesioner adalah metode pengumpulan data yang berbentuk pertanyaan yang akan diisi atau dijawab oleh responden.

Beberapa alasan digunakannya kuesioner adalah kuesioner terutama dipakai untuk mengukur variabel yang bersifat faktual, untuk memperoleh informasi yang relevan dengan tujuan penelitian, dan untuk memperoleh informasi dengan validitas dan rehabilitas setinggi mungkin. Kuesioner ini diberikan kepada mahasiswa Tadris Biologi IAIN Jember kelas biologi 1 angkatan 2019. Kuesioner diberikan secara online kepada responden pada tanggal 19 Mei 2020 tepat pukul 10.40 WIB. Penelitian ini dilakukan selama 1 minggu sejak kuesioner diberikan kepada responden. Selain itu, dilakukan pengecekan terhadap hasil jawaban dari responden setiap dua hari sekali. Diketahui dari 35 mahasiswa kelas biologi 1 angkatan 2019 yang dijadikan responden, terdapat 18 mahasiswa yang mengisi kuesioner dan sisanya 17 mahasiswa tidak mengisi kuesioner tersebut.

\section{HASIL}

Data tentang pengaruh pembelajaran sistem daring dalam memahami mata kuliah biokimia diperoleh dengan menggunakan kuesioner. Jenis angket yang diberikan adalah angket terbuka, artinya responden mendapat kebebasan untuk memberikan jawaban atau tanggapan. Angket yang diberikan berisi sebanyak enam item soal.

\section{Tabel 1. Hasil Penelitian}

\begin{tabular}{|c|l|l|c|}
\hline \multirow{2}{*}{ No. } & \multicolumn{2}{|c|}{ Responden } & \multicolumn{2}{|c|}{ Pemahaman terhadap Biokimia } \\
\cline { 3 - 4 } & & Positif & Negatif \\
\hline 1. & Responden 1 & & $\square$ \\
\hline
\end{tabular}




\begin{tabular}{|c|c|c|c|}
\hline 2. & Responden 2 & & $\square$ \\
\hline 3. & Responden 3 & & 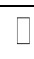 \\
\hline 4. & Responden 4 & & $\square$ \\
\hline 5. & Responden 5 & & 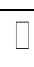 \\
\hline 6. & Responden 6 & & $\bar{\square}$ \\
\hline 7. & Responden 7 & 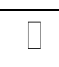 & \\
\hline 8. & Responden 8 & & ] \\
\hline 9. & Responden 9 & & ( \\
\hline 10. & Responden 10 & & ( \\
\hline 11. & Responden 11 & & $\bar{\square}$ \\
\hline 12. & Responden 12 & & $\square$ \\
\hline 13. & Responden 13 & & $\square$ \\
\hline 14. & Responden 14 & & $\square$ \\
\hline 15. & Responden 15 & & ] \\
\hline 16. & Responden 16 & & ( \\
\hline 17. & Responden 17 & & $\square$ \\
\hline 18. & Responden 18 & & ( \\
\hline
\end{tabular}

Keterangan:

Positif = mudah memahami materi matakuliah biokimia

Negatif = sulit memahami materi matakuliah biokimia

Berdasarkan jawaban dan tanggapan dari responden, terdapat 1 responden yang mudah dalam memahami mata kuliah biokimia dan 17 responden kesulitan dalam memahami matakuliah tersebut. Banyak dari mereka yang berpendapat bahwa dengan pembelajaran daring membuatnya menjadi kesulitan dalam memahami materi biokimia yang disampaikan dan dalam mempertanyakan materi yang belum mereka pahami menjadi terbatas. Selain itu, terdapat problematika lain yang dihadapi oleh responden seperti kesulitan dalam hal jaringan internet dan masalah kuota data yang terbatas. Sehingga dengan adanya pembelajaran sistem daring pada mata kuliah biokimia menjadi tidak efektif dan akan berpengaruh terhadap prestasi belajar mahasiswa.

\section{PEMBAHASAN}

Mata kuliah biokimia merupakan mata kuliah yang harus benar-benar difahami oleh mahasiswa maupun mahasiswi tadris biologi. Karena mata kuliah ini lebih spesifik bagian dari pokok biologi. Namun, efektifitasnya menurun disaat pembelajaran sistem daring dit- 
erapkan pada mata kuliah ini. Para responden yang menanggapi beberapa pertanyaan peneliti mengaku sulit memahami dan mencerna beberapa materi, akibat adanya faktor kendala yang berbeda pada masing-masing mahasiswa.

Tingkat pemahaman mahasiswa yang berbeda-beda mungkin menjadi masalah di saat individu tidak saling berkomunikasi secara langsung. Responden juga mengklaim bahwa mereka kesulitan disaat menemukan kosa-kata baru didalam materi, hal tersebut membuat pemahamannya terkendala dikarenakan istilah tersebut masih belum difahaminya. Selain beberapa faktor internal tersebut, yang menjadi kunci sulitnya pemahaman mahasiswa juga ada pada media elektronik nya.

Pembelajaran dengan sistem daring memang memudahkan kita belajar dimana saja dan kapan saja. Namun, sebagian mahasiswa mengeluh ketersediaan lingkungan atau tempat yang tidak memadai untuk terkoneksi dalam jaringan internet yang stabil. Mengingat mahasiswa berangkat dari berbagai daerah untuk melanjutkan kuliahnya dikota. Di sisi lain, secara garis besar tingkat keberhasilan dari pembelajaran sistem daring ini juga di tentukan dari baik dan buruknya media elektronik yang mahasiswa pakai. Media elektronik yang tidak sesuai atau tidak cocok, juga akan menghambat mahasiswa dalam mencari pemahamannya sendiri di sumber lainnya.

Menurut Drs Thursan Hakim (2010) ada beberapa prinsip pembelajaran agar lebih efektif dan berjalan dengan baik. Yaitu diantaranya :

1. Belajar memerlukan kemauan yang kuat.

Hal yang sering terjadi pada mahasiswa adalah bagaimana membuat kemauan belajarnya kuat dan stabil. Untuk mempunyai kemauan belajar yang kuat dan stabil, tentu mahasiswa harus mempunyai tujuan belajar yang jelas. Terutama dengan menetapkan tujuan yang jelas sebelum memilih mata kuliah yang akan dipelajarinya. Tujuan yang jelas dan benar-benar diinginkan seseorang, akan menyebabkan orang tersebut selalu berusaha untuk belajar dengan rajin agar apa yang menjadi tujuannya itu tercapai.

2. Keberhasilan belajar ditentukan oleh banyak faktor.

Faktor-faktor yang mempengaruhi atau menentukan keberhasilan belajar itu banyak. Ada kalanya juga individu yang satu memerlukan faktor yang berbeda daripada individu lain di dalam mencapai keberhasilan belajar. Secara garis besar, Faktor-faktor yang mempengaruhi keberhasilan belajar itu dapat dibagi menjadi 2 bagian yaitu: faktor internal dan faktor eksternal.

Faktor internal adalah faktor yang terdapat pada diri individu itu sendiri. Seperti kesehatan jasmani dan rohani, kecerdasan, daya ingat, kemauan, dan bakat. Faktor ekster- 
nal adalah faktor yang terdapat diluar diri individu yang bersangkutan. Seperti keadaan lingkungan rumah, kampus, media elektronik, dan lain sebagainya.

Setiap orang tentu saja mempunyai kelemahan dan kelebihan yang berbeda satu sama lain. Dalam hal ini, yang sangat perlu dilakukan adalah bagaimana agar seseorang dapat menutupi kelemahannya pada segi tertentu dengan kelebihan segi-segi lainnya.

3. Belajar secara keseluruhan akan lebih berhasil daripada belajar secara terbagi-bagi.

Cara belajar seperti ini akan memungkinkan seseorang untuk dapat mengerti suatu pokok pelajaran dengan lebih cepat dan lebih mudah. Hasilnya juga akan jauh lebih jelas daripada belajar bagian demi bagian. Bagi mahasiswa prinsip ini dapat diterapkan dengan cara meringkas materi pelajaran dalam satu skema, intisari dan tabel. Dengan demikian, bagian-bagian materi pelajaran yang tadinya tampak banyak akan terlihat jelas secara keseluruhan.

\section{Proses belajar memerlukan metode yang tepat.}

Proses belajar dengan metode tepat akan memungkinkan seorang mahasiswa menguasai ilmu dengan mudah dan cepat, sesuai dengan kapasitas tenaga dan fikiran yang dikeluarkan. Dengan kata lain, metode belajar yang tepat tersebut akan memungkinkan mahasiswa lebih memudahkan dalam proses pencarian pemahamannya sendiri dengan efektif dan efisien.

5. Belajar memerlukan adanya kesesuaian antara dosen dan mahasiswa.

Dalam prinsip belajar ini, sangat mempengaruhi seorang murid atau mahasiswa dalam menyenangi suatu pelajaran. Hal ini tentu saja akan mempengaruhi motivasi individu dalam belajar. Karena itu, dosen dan pengajar yang baik tentunya akan selalu berusaha untuk menerapkan metode pengajaran yang benar-benar sesuai dengan kemampuan muridmuridnya. Dengan kesesuaian ini akan membuat murid-muridnya senang dan bersemangat serta merasa mudah dalam mempelajari sebuah studi.

Namun juga yang sangat perlu diperhatikan adalah jangan sampai seorang mahasiswa mengabaikan sama sekali suatu bidang sekarang, dengan diterapkannya cara belajar siswa aktif (CBSA), para murid dituntut untuk bisa belajar sendiri, tanpa harus banyak mengeluh tentang ketidaksenangannya terhadap seorang guru atau pengajar.

\section{KESIMPULAN DAN SARAN}

\section{Kesimpulan}

Berdasarkan hasil penelitian yang didapatkan bahwa pembelajaran sistem daring pada mata kuliah biokimia bagi mahasiswa Tadris Biologi IAIN Jember menyebabkan mahasiswa 
kesulitan dalam memahami materi yang disampaikan. Banyak faktor yang menyebabkan hal itu terjadi. Selain kesulitan memahami materi yang disampaikan, pembelajaran sistem daring dirasa tidak efektif oleh mahasiswa.

\section{Saran}

1. Pembelajaran secara sistem daring pada mata kuliah biokimia sebaiknya menerapkan metode pengajaran yang benar-benar sesuai dengan kemampuan mahasiswa.

2. Pembelajaran yang dilaksanakan secara sistem daring pada mata kuliah biokimia hendaknya menggunakan media yang tepat, seperti menggunakan media sosial yang dapat memudahkan mahasiswa dalam memahami materi yang disampaikan.

\section{DAFTAR RUJUKAN}

Arsyad, Azhar. 2011. Media Pembelajaran. Jakarta: Penerbit Rajawali Pers.

Sobron, DKK. "Persepsi Siswa dalam Studi Pengaruh Daring Learing Terhadap Minat Belajar IPA ". Vol.1 (2019), 30-33.

Hakim, Thursan. 2010. Belajar secara Efektif. Jakarta: Pustaka Pembangunan Swadaya Nusantara.

Gulo, W. dan Hardiwati, Yovita. 2002. Metodologi penelitian. Jakarta: Grasindo.

Djaali, Haji. DKK. 2008. Pengukuran dalam Bidang Pendidikan. Jakarta: Grasindo. 